\title{
Psychological Contracts, Job Stress, and Turnover Intention for Salesperson Retail Company
}

\author{
${ }^{1}$ Retno Dwiyanti ${ }^{*}{ }^{2}$ Hazalizah Binti Hamzah, ${ }^{3}$ Nurul Ain Hidayah Binti Abas \\ ${ }^{1}$ Universitas Muhammadiyah Purwokerto, Indonesia, \\ ${ }^{2,3}$ Universiti Pendidikan Sultan Idris, Malaysia
}

\begin{abstract}
Employees are social beings who have their own backgrounds, personalities and ways of thinking Employees also often have different ways of dealing with problems, including in terms of handling stress so that the company cannot predict the employee's attitude. Poor relations between employees and the company can also be an indication of the behavior of employees who move from one company to another. The purpose of this study was to determine the relationship between psychological contracts and work stress with turnover intention. The sample of this study was 274 employees of the sales department of retail companies in Purwokerto. Data were collected using a psychological contract scale, job stress scale, and turnover intention questionnaire. The results showed that there was a significant relationship between psychological contracts with turnover intention $(\beta=-0.276, \mathrm{t}=3.562, \mathrm{p}=0.000)$. The relationship between job stress and turnover intention also showed a significant relationship $(\beta=0.213, \mathrm{t}=3.778, \mathrm{p}=$ $0.000)$.
\end{abstract}

Keywords: Psychological Contracts, Job Stress, Turnover Intention.

\section{Introduction}

Every company will compete in making strategies and taking appropriate policies as an alternative to achieving goals. To achieve these objectives, the role of resources is needed in facing various challenges. Human resources are the main resources that are able to compete. According to (Olivia, 2014), the success of a company depends on employee performance. Individuals who meet the requirements are individuals who have good performance. Qualified human resources will be the main support for the smooth running of activities in the company. In fact, not all employees are able to obtain satisfactory performance.

The most important company asset is human resources because humans are able to manage the company's resources and are able to generate profits for the company (Simamora, 2006). If the company does not care about the potential of its human resources, most employees will choose to leave the company. Implementation of inappropriate policies can have a negative impact on employee work attitudes, such as turnover. The desire of employees to quit can be caused by internal factors including the values and personality possessed by employees. In addition to individual factors, factors related to matters outside the employee, such as coworkers, superiors, and applicable company policies also affect turnover rates. Turnover intentions are defined as intermediaries between attitudes that influence the desire to quit from work and quit-work behavior(Glissmeyer, Cruces, \& Bishop, 2008).

JobsDB Indonesia conducted a survey which was attended by 2,324 respondents in Indonesia with various occupational fields and career levels. The survey results show that as many as $80 \%$ of respondents want to move within the next 12 months, this is caused by the lack of employee satisfaction with the systems and work processes adopted by the company (Praditya, 2015). Turnover intentions are marked by increased absenteeism, laziness in doing work, violations of work regulations are increasing, opposition to leadership and behavior that harms the company (Sianipar \& Haryanti, 2014).

Job stress is also one of the problems that are often faced by employees. Job stress has become a common thing, more and more people are complaining about stress due to excessive work, job insecurity and the increasing pace of life. Job stress can be dangerous from time to time, causing increased intention to change 
jobs, reducing interaction with colleague and coworkers, increasing conflict with family and friends, absence, substance abuse, work fatigue, health problems, and even death (Lambert, Edwards, Camp, \& Saylor, 2005). Increased workload and other factors can cause stress and discomfort for employees that interfere with performance. (Sugiyanto \& Irawati, 2016) Suggested that physical fatigue causes work-family conflicts among employees. If this happens continuously, the desire to move becomes stronger. As said by (Syahronica \& Ruhana, 2015) that stress is the dominant factor affecting turnover intentions, this is in line with the opinion of (Manurung \& Ratnawati, 2012)which states that stress has a positive effect on turnover intentions on employees.

According to (Tekleab \& Taylor, 2005) violations of psychological contracts are also one of the factors that cause intentions to move. When employees assume that their superiors are violating their promises to employees, then employees will assume that the relationship between them and superiors is an unequal relationship (Stoner, Gallagher, \& Stoner, 2011). Therefore, to improve good relations that are mutually beneficial between superiors and subordinates psychological contracts are needed. Strong psychological contracts with employees will increase work productivity and employee performance. According to (Hui \& Law, 2000) the behavior of employees who show work results that match the expectations of superiors will be more considered than work behavior that is not real. Psychological contracts are seen as tangible forms of the work that employees give to the company. Employees who can make a higher contribution to the company will be rewarded by superiors (eg promotion) than those who contribute less to the company.

Based on this description, this study aims to determine the relationship between psychological contracts and work stress with turnover intentions.

\section{Method}

The approach in this study uses quantitative methods. The subjects of this research are 274 employees of a retail salesperson in Purwokerto. Data collection methods used were work stress questionnaire, psychological contract scale, and turnover intention questionnaire.

Job stress is measured using a questionnaire developed by (Parker \& Decotiis, 1983). Participants were asked to rate each of the 13 items using a Likert scale. The Psychology Contract Scale, developed by (Dwiyanti, 2006) consists of three dimensions, namely Transactional, Relational, and Balanced. The turnover intention questionnaire consisted of three items that measured respondents' intention to quit their jobs. Turnover intention items were adopted from Khatri, Fern, and Budhwar (Yücel, 2012).

Subjects respond to all items based on a 5-point Likert scale $(1=$ strongly disagree to $5=$ strongly agree). In this study, the work stress questionnaire has an alpha reliability of 0.88 while the psychological contract questionnaire has alpha reliability of 0.893 and the turnover intention questionnaire has a reliability of 0.895 .

Analysis of the data used is Structural Equation Modeling (SEM) PLS. SEM analysis is used because it is able to test complex and multi-level hypotheses simultaneously, errors in each observation are not ignored but are still analyzed, so SEM is more accurate for analyzing questionnaire data involving perception, being able to analyze reciprocal models simultaneously, where this model cannot be solved by linear regression analysis simultaneously.

\section{Result and Discussion}

In this study hypothesis testing used Partial Least Square (PLS) analysis techniques with the SmartPLS 3.0 program. Following is the scheme of the PLS program model that was tested: 


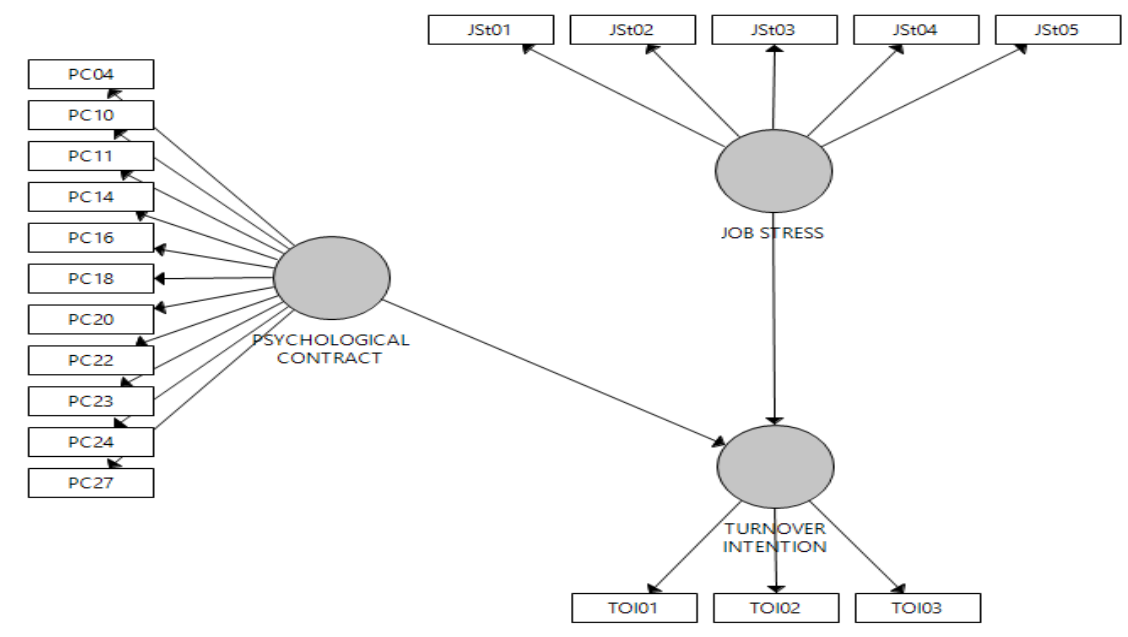

The summary of the measurement model in this study is presented in Table 1 below.

Table 1: Result of measurement model

\begin{tabular}{|c|c|c|c|c|c|c|c|}
\hline $\begin{array}{l}\text { Latent } \\
\text { Variable }\end{array}$ & Items & MV & SD & $\begin{array}{l}\text { Outer } \\
\text { Loading }\end{array}$ & $\begin{array}{l}\text { Cronbach's } \\
\text { Alpha }\end{array}$ & $\mathbf{C R}$ & AVE \\
\hline \multicolumn{8}{|c|}{ Psychological Contract } \\
\hline & $\mathrm{PC} 04$ & 3,41 & 0,9 & 0,743 & 0,931 & 0,941 & 0,592 \\
\hline & PC10 & 3,46 & 0,84 & 0,701 & & & \\
\hline & PC11 & 3,32 & 1,08 & 0,765 & & & \\
\hline & $\mathrm{PC} 14$ & 3,54 & 0,83 & 0,706 & & & \\
\hline & PC16 & 3,84 & 0,75 & 0,829 & & & \\
\hline & PC18 & 3,93 & 0,75 & 0,804 & & & \\
\hline & $\mathrm{PC} 20$ & 3,77 & 0,74 & 0,760 & & & \\
\hline & $\mathrm{PC} 22$ & 3,84 & 0,65 & 0,802 & & & \\
\hline & $\mathrm{PC} 23$ & 3,8 & 0,67 & 0,784 & & & \\
\hline & $\mathrm{PC} 24$ & 3,89 & 0,68 & 0,795 & & & \\
\hline & PC27 & 3,76 & 0,8 & 0,764 & & & \\
\hline \multicolumn{8}{|c|}{ Job Stress } \\
\hline & JST01 & 2,854 & 1,02 & 0,801 & 0,837 & 0,885 & 0,606 \\
\hline & JST02 & 2,836 & 0,971 & 0,826 & & & \\
\hline & JST03 & 2,325 & 0,775 & 0,731 & & & \\
\hline & JST04 & 2,255 & 0,799 & 0,765 & & & \\
\hline & JST05 & 2,661 & 0,778 & 0,768 & & & \\
\hline \multicolumn{8}{|c|}{ Turnover Intention } \\
\hline & TOI01 & 2,314 & 0,875 & 0,912 & 0,865 & 0,917 & 0,788 \\
\hline & TOI02 & 2,438 & 0,837 & 0,890 & & & \\
\hline & TOI03 & 2,427 & 0,896 & 0,860 & & & \\
\hline
\end{tabular}


Note: Mean value (MV); Standard deviation (SD); Composite reliability (CR); Average variance exchange (AVE).

Based on the test results of the measurement models shown in table 3, all indicators have a loading factor > 0.6 and average variance extracted (AVE) $>0.5$, so the data above shows all the indicators declared to be feasible or reliable for research use. According to Hair, et al (2014) the results revealed good goods loading above the recommended threshold of 0.7. while according to Hair (quoted by Ghozali, 2014) an outer loading value between $0.5-0.6$ is considered sufficient to meet the convergent validity requirements. The data above shows there are no variable indicators whose outer loading values are below 0.5, so all indicators are declared valid for research use and can be used for further analysis. The results of the average variance extracted (AVE) indicate values above 0.5 are the recommended threshold values (Hair, et. Al., 2006).

Composite Reliability (CR) is a part that is used to test the reliability value of an indicator on a variable. Reliability testing with composite reliability can be strengthened using alpha cronbach values. The recommended minimum composite reliability value is 0.70 , although the value of composite reliability from 0.60 to 0.70 can still be considered acceptable (Hair, Ringle, and Sarstedt, 2011).

The results of hypothesis testing can be observed in Table 2. Hypothesis testing is done to analyze the causal relationship (causality) between the variables in the model based on critical ratio values (CR). In the case of PLS-SEM, CR is known as the t-stat value. The T-value is obtained through a bootstrap routine and must be more than 1.96 (Chin, 1998). If the t-stat value is higher than 1.96 (sig. 5\% two sides) and has a positive relationship (see hypothesis), the hypothesis is supported.

\section{Table 2: Results of the structural model analysis}

\begin{tabular}{|l|l|l|l|l|l|}
\hline Relationship & $\begin{array}{l}\text { Std } \\
\text { Beta }\end{array}$ & $\begin{array}{l}\text { Std } \\
\text { Error }\end{array}$ & $\begin{array}{l}\text { t- } \\
\text { value }\end{array}$ & $\begin{array}{l}\text { P } \\
\text { Values }\end{array}$ & Decision \\
\hline PC > TOI & $-0,276$ & 0,078 & 3,562 & 0,000 & Supported \\
\hline JSt > TOI & 0,213 & 0,056 & 3,778 & 0,000 & Supported \\
\hline
\end{tabular}

Notes: *Significant at $\mathrm{p} \leq 0.05 ; * * \mathrm{p}<0.01 ; * * * \mathrm{p}<0.001 ; \mathrm{ns}=$ not significant.

Based on the results of the structural model in this study (table 2), it shows that there is a significant relationship of Psychological contract with Turnover Intention, which is shown by the Psychological contract $(\beta=-0.276, t=3.562, p=0.000)$, so the hypothesis is supported.

The results of this study support the study of Collins (2010) that psychological contracts significantly influence turnover intentions. Findings from this study indicate that employee turnover can be reduced if organizational leaders develop a good relationship with their employees based on mutual respect, trust, and obligation. Then utilize the relationship to understand and fulfill the unwritten contract that is felt to exist between the company and its employees. Chin and Hung (2013) consider it necessary to reduce the turnover intention level by considering the psychological contract and increasing the resilience of employees facing difficulties. The results also support the study of Clinton and Guest (2014) that violations of psychological contracts are positively and significantly related to turnover.

The results of research from (Wang, Li, Wang, \& Gao, 2017) show that transactional and relational psychological contracts have a significant impact on turnover intentions. The main findings from the study of (Umar \& Ringim, 2015) also show that transactional psychological contracts have a strong positive relationship with employee turnover intentions in private organizations in Nigeria. Also, the relational and balanced dimensions of psychological contracts are significantly related to the intention to move to leave a private organization. Findings (Moquin, Riemenschneider, \& Wakefield, 2019) show that Psychological Contract Breach affect turnover intentions. The higher the expectations that are not met, the more likely the employee will leave the organization.

Whereas job stress $(\beta=0.213, t=3.778, p=0.000)$ are supported for turnover intention. The results of this study are in line with (Arshadi \& Damiri, 2013) that work stress and desire to move have a positive relationship. These results also support research conducted by (Pahi, Hamid, \& Khalid, 2016) that job stress 
and turnover intention has a positive relationship when job stress increase than intension of leave also increase, job stress and turnover have a positive relationship.

The results of a study conducted by (Lee \& Woo, 2015) which concluded that work unrest is positively related to turnover intention. There are many researchers who find that the greater the amount of stress, the higher the employee turnover intention (Chen, Lin, \& Lien, 2011). The results of (Kafashpoor, Sadeghian, Shakori, \& Kavoosi, 2014) research also show that job stress has a direct and positive relationship with turnover intention. There are many researchers who have identified that there is a significant impact of job stress on turnover intentions.

The findings of this study differ from the results of research conducted by (Paillé, 2010), which proves that work stress has a negative and significant effect on turnover intentions. The least strong relationship between dimensions on work stress variables and turnover intentions causes the effect of work stress on turnover intentions to be insignificant. This can be interpreted that if there is a change in employee work stress the influence on the desires of employees leaving the company is not noticeable. Referring to the job stress model from Koslowsky (in Wisantyo \& Madiistriyatno, 2015) stressors can produce different responses, not always making employees want to leave the company.

\section{Conclusion}

The results can be concluded that there is a significant relationship between psychological contracts and job stress with Turnover Intention. Findings from this study indicate that employee turnover can be reduced if organizational leaders develop a good relationship with their employees based on mutual respect, trust, and obligation. Future research is expected to be able to add organizational variables that might contribute to reducing the turnover rate, for example, organizational justice and organizational culture.

\section{References}

[1.] Arshadi, N., \& Damiri, H. (2013). The Relationship of Job Stress with Turnover Intention and Job Performance: Moderating Role of OBSE. Procedia - Social and Behavioral Sciences, 84(2003), 706-710. https://doi.org/10.1016/j.sbspro.2013.06.631.

[2.] Chin, W. W. (1998). The partial least squares approach for structural equation modeling. In G. A. Marcoulides (Ed.), Modern methods for business research (pp. 295-336). London: Lawrence Erbaum Associates.

[3.] Chin, P.-L., \& Hung, M.-L. (2013). Psychological Contract Breach And Turnover Intention: The Moderating Roles Of Adversity Quotient And Gender, 41(1), 843-860.

[4.] Chen, M. F., Lin, C. P., \& Lien, G. Y. (2011). Modelling job stress as a mediating role in predicting turnover intention. Service Industries Journal, 31(8), 1327-1345. https://doi.org/10.1080/02642060903437543.

[5.] Collins, M. D. (2010). The Effect Of Psychological Contract Fulfillment On Manager Turnover Intentions And Its Role As A Mediator In A Casual, Limited-Service Restaurant Environment. International Journal Of Hospitality Management, 29 (4), 736-742.

[6.] Clinton, M.E and Guest, D.E. (2014) Psychological contract breach and voluntary turnover: Testing a multiple mediation model. Journal of Occupational and Organizational Psychology, 87, 200-207

[7.] Dwiyanti, R. (2006). Peran Kecerdasan Emosi Dan Budaya Organisasi Terhadap Kontrak Psikologis.

[8.] Ghozali, I. (2014) Structural Equation Modeling - Metode Alternatif dengan Partial Least Squares (PLS) Semarang: Universitas Diponegoro.

[9.] Glissmeyer, M., Cruces, L., \& Bishop, J. W. (2008). Role Conflict , Role Ambiguity , And Intention To Quit The Organization: The Case Of Law Enforcement Officers '. Academy of Management Journal, 40(1), 458-469.

[10.] Hair Jr, J. F., Hult, G. T. M., Ringle, C., \& Sarstedt, M. (2014). A primer on partial least squares structural equation modeling (PLS-SEM). Sage Publications.

[11.] Hair, J., Black, B. Babin, B., Anderson, R. and Tatham, R. (2006). Multivariate Data Analysis (6th edition). Upper Saddle River, NJ: Prentice-Hall. 
[12.] Hair J.F., Ringle C.M. \& Sarstedt M. 2011. PLS-SEM: Indeed a silver bullet. The Journal of Marketing Theory and Practice 19 (2): 139-152.

[13.] Hui, C., \& Law, K. K. S. (2000). Instrumental Values of Organizational Citizenship Behavior for Promotion: A Instrumental Values of Organizational Citizenship Behavior for Promotion: (November 2014). https://doi.org/10.1037/0021-9010.85.5.822.

[14.] Kafashpoor, A., Sadeghian, S., Shakori, N., \& Kavoosi, S. (2014). The Impact of Job Stress on Turnover Intention Mediating role of Job Satisfaction and Affective Commitment; Case Study: Mashhad 's Public Hospitals. Applied Mathematics in Engineering, Management and Technology, 2(1), 96-102.

[15.] Lambert, E. G., Edwards, C., Camp, S. D., \& Saylor, W. G. (2005). Here today, gone tomorrow, back again the next day: Antecedents of correctional officer absenteeism. Journal of Criminal Justice, 33, 165-175.

[16.] Lee, S. H., \& Jeong, D. Y. (2017). Job Insecurity And Turnover Intention: Organizational Commitment As Mediator. Social Behavior And Personality, 45(4), 529-536.

[17.] Lee, S.-J., \& Woo, H.-J. (2015). Structural Relationships among Job Embeddedness, Emotional Intelligence, Social Support and Turnover Intention of Nurses. Journal of Korean Academy of Nursing Administration, 21(1), 32. https://doi.org/10.11111/jkana.2015.21.1.32.

[18.] Manurung, M. T., \& Ratnawati, I. (2012). Analisis Pengaruh Stres Kerja Dan Kepuasan Kerja Terhadap Turnover Intention Karyawan ( Studi Pada STIKES Widya Husada Semarang ). 1, 1-13.

[19.] Moquin, R., K. Riemenschneider, C., \& L. Wakefield, R. (2019). Psychological Contract and Turnover Intention in the Information Technology Profession. Information Systems Management, 36(2), 111-125. https://doi.org/10.1080/10580530.2019.1587574.

[20.] Olivia, D. O. (2014). Kepribadian Hardiness Dengan Prestasi Kerja Pada Karyawan Bank. Jurnal Ilmiah Psikologi Terapan, 02(01), 115-129.

[21.] Pahi, M. H., Hamid, K. A., \& Khalid, N. (2016). Save talent of banking sector of Pakistan: Mediating job satisfaction between job stress and employee turnover intention. International Review of Management and Marketing, 6(3), 617-624.

[22.] Paillé, P. (2010). Perceived Stressful Work, Citizenship Behaviour and Intention to Leave the Organization in a High Turnover Environment: Examining the Mediating Role of Job Satisfaction. Journal of Management Research, 3(1), 1-14. https://doi.org/10.5296/jmr.v3i1.487.

[23.] Parker, D. E., \& Decotiis, T. A. . (1983). Organizational Determinants of Job Stress. Organizational Behavior And Human Performance, 32, 160-177.

[24.] Praditya, I. I. (2015). 73\% Karyawan di RI Tak Puas dengan Pekerjaannya.

[25.] Sianipar, R. B., \& Haryanti, K. (2014). Kerja Dengan Intensi Turnover Pada Karyawan. 13(1), 98-114.

[26.] Simamora, H. (2006). Manajemen Sumber Daya Manusia (S. T. I. E. YKPN., Ed.). Yogyakarta.

[27.] Stoner, J. S., Gallagher, V. C., \& Stoner, C. R. (2011). The interactive effects of emotional family support and perceived supervisor loyalty on the psychological contract breach -turnover relationship. Journal of Managerial Issues, 23(2), 124-143.

[28.] Sugiyanto, E., \& Irawati, Z. (2016). Konflik Pekerja-Keluarga dan Pengaruhnya Terhadap Kinerja Pegawai ( Studi Kasus Rumah Sakit Berbasis Islam di Surakarta ). 9(1), 27-52.

[29.] Sunarso, W. (2000). Hubungan antara Kepuasan Kerja dan Peran Faktor-faktornya terhadap Intensi Turnover Pada Wiraniaga Toserba Progo Yogyakarta. Skripsi (tidak diterbitkan). Yoyakarta: Fakultas Psikologi UGM.

[30.] Syahronica, G., \& Ruhana, I. (2015). Pengaruh Kepuasan Kerja Dan Stres Kerja Terhadap Turnover Intention ( Studi Pada Karyawan Departemen Dunia Fantasi Pt Pembangunan Jaya Ancol, Tbk). 20(1), 1-6.

[31.] Tekleab, A. G., \& Taylor, M. S. (2005). Extending The Chain Of Relationships Among Organizational Justice, Social Exchange, And Employee Reactions: The Role Of Contract Violations. 48(1), 146-157.

[32.] Umar, S., \& Ringim, K. J. (2015). Psychological Contract and Employee Turnover Intention among Nigerian Employees in Private Organizations. Management International Conference, (May), 219-229. 
[33.] Wang, Y., Li, Z., Wang, Y., \& Gao, F. (2017). Psychological Contract and Turnover Intention: The Mediating Role of Organizational Commitment. Journal of Human Resource and Sustainability Studies, 05(01), 21-35. https://doi.org/10.4236/jhrss.2017.51003.

[34.] Wisantyo, N. I., \& Madiistriyatno, H. (2015). Analisis Pengaruh Stres Kerja Dan Kepuasan Kerja Terhadap Turnover Intention Karyawan (Studi padaLembagaPengelola Dana Bergulir Koperasi danUsaha Mikro, Kecil dan Menengah ) Jurnal MIX, 5(1), 54-69. https://doi.org/10.5897/ERR2015.

[35.] Yücel, İ. (2012). Examining the Relationships among Job Satisfaction, Organizational Commitment, and Turnover Intention : An Empirical Study. International Journal of Business and Management, 7(20), 44-58. https://doi.org/10.5539/ijbm.v7n20p44. 